\title{
RESULTS OF A STUDY OF CYPRIPEDIUM IN SEVERAL REGIONS OF SIBERIA (RUSSIA)
}

\author{
EKATERINA ZHELEZNAYA
}

Timiryazev State Biology Museum, Moscow, Russia

Corresponding author: Zheleznaya@yandex.ru

\section{ABSTRACT}

This study of populations of Cypripedium calceolus L., Cypripedium macranthon Sw. and their hybrid Cypripedium ventricosum Sw. in several regions of Siberia was carried out in 2009-2014. Isolated and mixed populations of the two species and their hybrid were surveyed. In sympatric populations, C. macranthon is most common in the central part and those of $C$. calceolus prevail in the western part of the range. Mature vegetative and/or reproductive shoots were present but vegetative reproduction was clearly most important in most of the populations investigated. Five colour variations were recorded for $C$. ventricosum. All species benefit from the increase in the intensity of light reaching ground level in forests after ground fires in spring destroy young trees and undergrowth. Vegetative reproduction and the size of the plants increases in burnt areas. Important factors determining the size and the ontogenetic structure of Cypripedium populations are: the duration of the growing season, the ecological conditions, the activities of pollinators and the relationships among the three species in sympatric populations.

Keywords: Cypripedium, orchids, Siberia

\section{Introduction}

The life history of rare species of plants in plant communities must be studied in detail in order to understand how their populations are regulated. Cypripedium calceolus L., Cypripedium macranthon Sw. and their interspecific hybrid Cypripedium ventricosum Sw. are included in the Red Data Book of the Russian Federation (2008) and in many regional Red Data books. These species are listed in Appendix II of CITES. C. calceolus is also listed in various international conventions and directives (Terschuren 1999). Isolated and mixed populations of the two species and the hybrid occur in the east of the European part, in the Middle of the Urals, in the south of Siberia and the Far East of Russia.

In Russia, C. calceolus occurs in the forest zone in the European part of the country, in southern Siberia and the Far East. C. macranthon occurs in the southwest of Central Russia, in the Volga-Kama region, the Ural region, the south of Siberia and in the Far East. The hybrid C. ventricosum occurs in the territory between the Urals and Vladivostok where the ranges of the two species overlap (Averyanov 1999, Fig. 1). The sizes of populations of these three rare species vary from solitary plants to thousands of individuals in different parts of their ranges. The most abundant populations occur on calcareous soils, in spring fens and on limestone slopes (Vakhrameeva et al. 2008). C. calceolus does not thrive if subject to competition from other herbaceous plants and low levels of illumination (Zaugolnova et al. 1992). Adult vegetative and/ or generative plants are dominant in most of the populations studied in coniferous, coniferous-broad-leaved, broad-leaved, small-leaved, coniferous-small-leaved forests and on transitional bogs (Varlygina and Matsenko 1987; Tatarenko 1996; Ishmuratova et al. 2003). The age spectrum of Cypripedium populations is 0:8:44:48 (juvenile : immature : vegetative : reproductive) (Tatarenko 1996). This ratio of ontogenetic groups indicates the importance of vegetative reproduction in populations of this species. The ratio of ontogenetic groups differs from the basic spectrum only in populations of Cypripedium calceolus growing on slopes in river valleys, with a sparse moss and grass cover (Puchnina 1999), in pine forests with Sphagnum cover (Ishmuratova et al. 2003) and in wetland habitats and on limestone outcrops (Teteryuk 2003). A significant number of juvenile (58\%) and immature (52\%) plants were recorded in those populations that reproduced sexually as well as vegetatively. Apparently, the favourable conditions for the development of seedlings include sufficient moisture and light and the absence of competition from other species. The objectives of this study were: 1 ) to determine the number of sympatric and isolated populations of C. calceolus L., C. macranthon Sw. and C. ventricosum Sw.; 2) to identify common and specific features of the ontogenetic structure and reproduction in Cypripedium populations; 3 ) to study the spatial structure of Cypripedium populations; 4) to make detailed measurements of the morphometric traits in order to identify intraspecific and interspecific variation.

\section{Materials and Methods}

Research was carried out in (1) the south of the Krasnoyarsk Territory in 2009 and 2011, (2) in the Irkutsk region and the Republic of Buryatia in 2008, 2010, 2013 and 2014 and (3) in the Altai Republic in 2012 (Fig. 1). In total, 65 populations were studied.

1. Botanical surveys of plant communities with orchids were carried out on 3-10 plots $\left(100 \mathrm{~m}^{2}\right)$. A list plus 
the abundance of each species (Braun-Blanquet 1964) was compiled for each site. The classification of plant communities was based on the dominant species.

2. Above-ground shoot was the accounting unit for the rhizomatous species C. calceolus, C. macranthon and C. ventricosum (Zaugolnova et al. 1988). The ontogenetic stage was identified for each shoot based on the "concept of discrete ontogeny" (Gatzuk et al. 1980) developed in Russia. According to this concept, ontogeny of an individual plant is divided into 4 periods and 9 stages: I. Latent period (seed); II. Pre-reproductive period (seedling, juvenile (j), immature (im), mature vegetative (v)); III. Reproductive period (young, mature and old reproductive (g)); IV. Post-reproductive period (senescent (s)) (Rabotnov 1950; Uranov 1975; Zaugolnova et al. 1988). The post-reproductive period is rarely observed in orchids (Vakhrameeva and Tatarenko 1998).

3. For each species, 3-30 flowering shoots were measured in each population. Twenty traits were recorded: 1) number of leaves, 2) shoot height, 3 and 4) the length and width of the second leaf, 5) the number of ribs on the second leaf, 6 and 7) the length and width of the dorsal outer petal (sepal), 8 and 9) the length and width of the lateral petal (sepal), 10 and 11) the length and width of the inner petal, 12 and 13) the length and width of the labellum, 14) the depth of labellum, 15) the length of the hole in the labellum from the staminodium to forefront, 16) the width of the wrapped inside edge of the hole in the middle of the labellum, 17) the number of half-turns in the spiral inner petal, 18 and 19) the length and width of the bracts and 20) the length of the free parts of the lateral petal.

For statistical analyses, Excel 2003 and Statistica-6 were used.

\section{Results and Discussion}

The regions studied differed in their climates, in particular, the duration of the growing season and amount of annual precipitation. In the south of the Krasnoyarsk region and the Altai Nature Reserve, the growing season is the longest: 140-150 days. On the northeastern coast of Lake Baikal (Barguzinsky Nature Reserve) it is the shortest, 90 days. The highest rainfall was recorded in the mountains on the northeastern and southern coasts of Lake Baikal (about $1000 \mathrm{~mm}$ per year). The lowest annual rainfall was recorded in the south of the Krasnoyarsk Territory (about $300 \mathrm{~mm}$ per year).

Sympatric populations of Cypripedium grow in forests of pine, birch, larch or poplar, in both wet (margins of marshes) and dry habitats (limestone slopes). However, in all these habitats the canopy cover of the trees was between $0.3-0.5$, that of the undergrowth between $0.5-0.7$ or absent and that of grass between 5-60\%. Periodic surface fires regularly occur in Siberia in spring and destroy young trees and undergrowth, which increases the level of illumination in these forests. This promotes active veg-

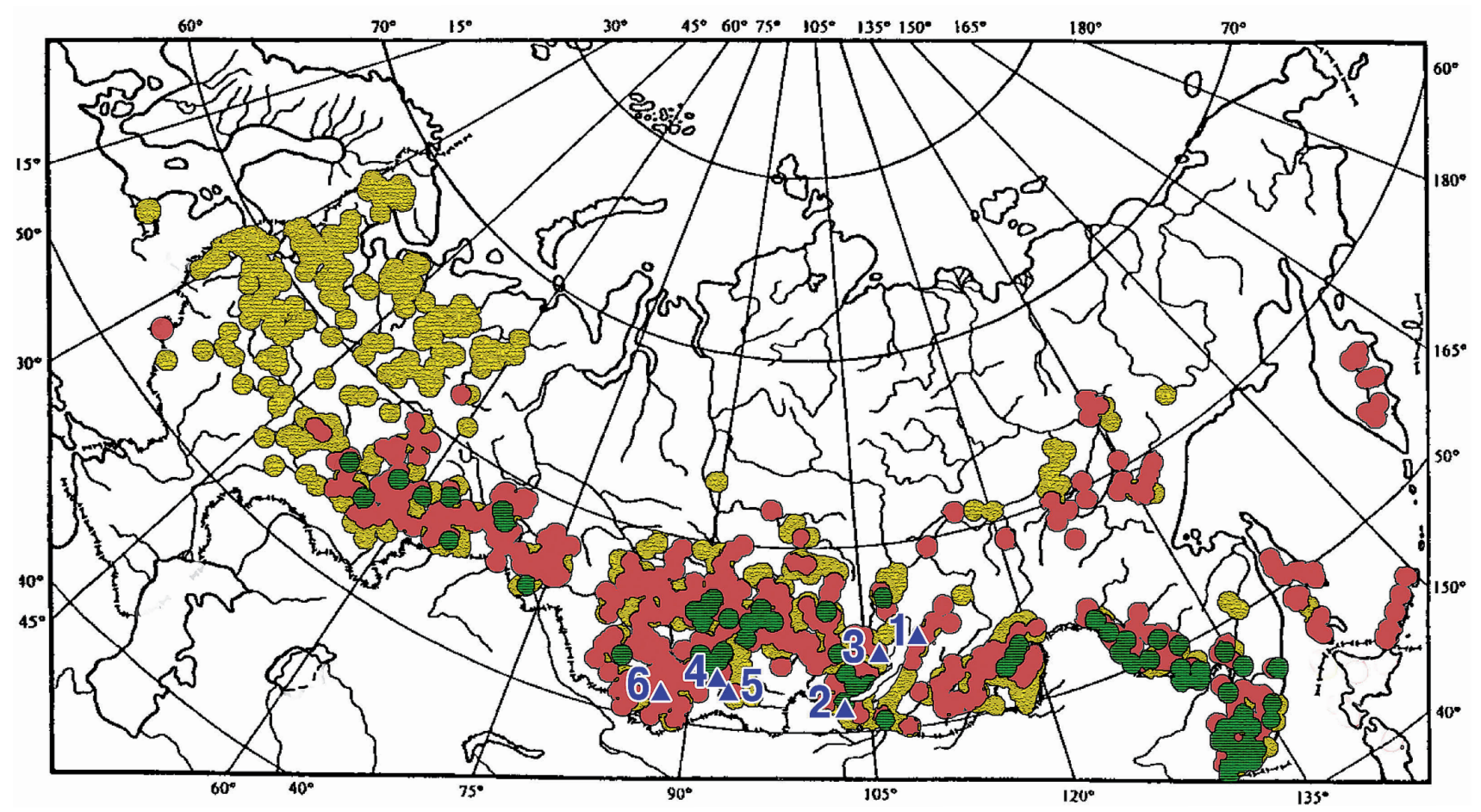

Fig. 1 Map showing the distributions of Cypripedium calceolus, C. macranthon and C. ventricosum (redrawn with additions from Averyanov 1999) and the locations of the areas surveyed in Russia. Cypripedium calceolus (yellow), Cypripedium macranthon (red), Cypripedium ventricosum (green). The locations of the areas surveyed: 1. Northeastern Baikal (the Barguzin Nature Reserve), 2. Southern Baikal, 3. Western Baikal (the Baikal-Lensky Nature Reserve), 4. Minusinsk Basin (the Shushensky Pine Forest National Park), 5. Usinsk Basin, 6. Lake Teletskoye (the Altai Nature Reserve). 


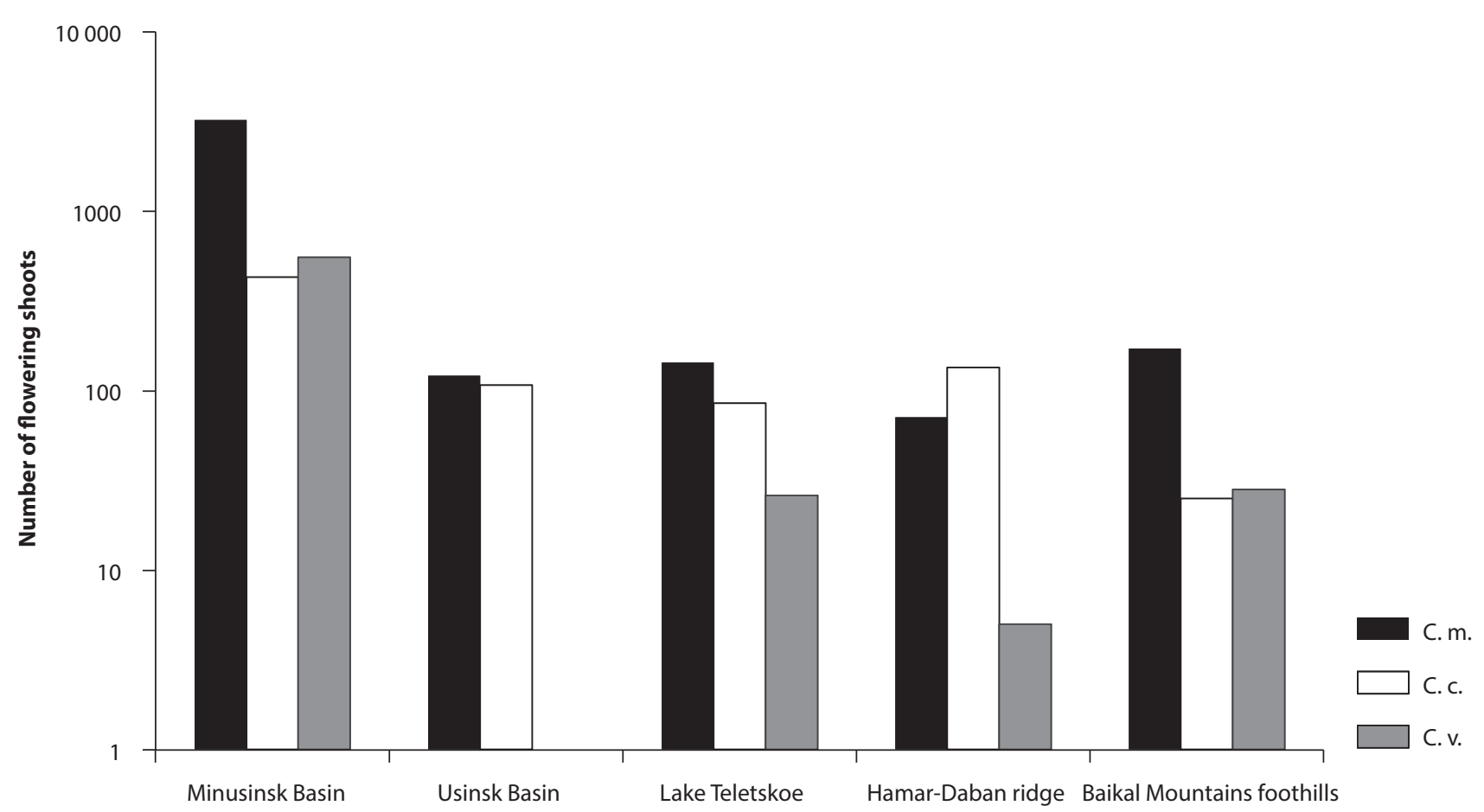

Fig. 2 The numbers of flowering shoots recorded in sympatric populations of Cypripedium macranthon, C. ventricosum and C. calceolus in different areas in Siberia.

etative reproduction and growth of Cypripedium, as described for similar conditions in other regions (Smirnov 1969; Dementieva 1985). The largest population of $C y$ pripedium (about 5,000 shoots), occupying an area of about $56,620 \mathrm{~m}^{2}$, was recorded in the Minusinsk Basin (Fig. 2). There are populations consisting of a few plants in the western foothills of the Baikal Ridge scattered over a $530 \mathrm{~m}$ length along the right bank of the Lena River. The average density was $0.04-6.00$ shoots $/ \mathrm{m}^{2}$.

C. macranthon plants prevailed in all sympatric populations of Cypripedium, except those on the KhamarDaban Ridge (Fig. 2). This is typical of populations in the central part of the range, but not the more westerly habitats, where C. calceolus was more abundant (Mamaev

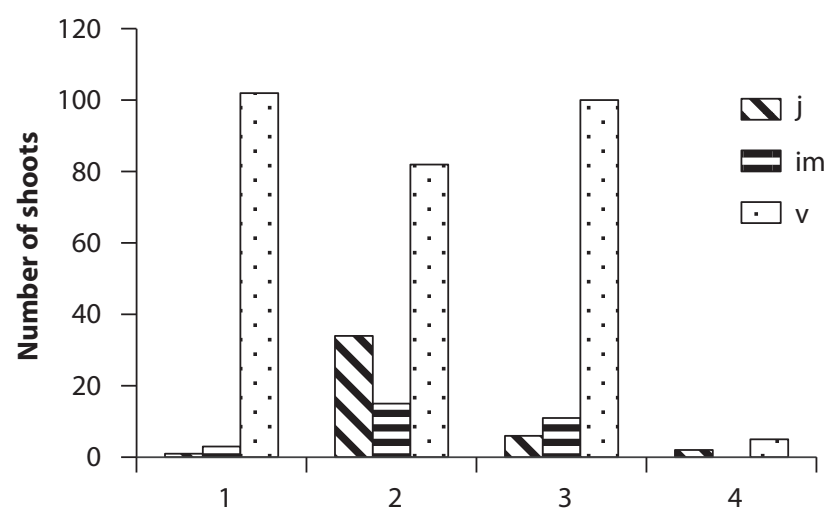

Fig. 3 Numbers of non-flowering shoots recorded in sympatric populations of Cypripedium in the Altai Nature Reserve in 2012; j juvenile plants, im - immature plants, v - vegetative plants. et al. 2004). The sympatric populations of Cypripedium on the Khamar-Daban Ridge are under significant anthropogenic pressure. The C. macranthon population has suffered the most serious damage. It is possible that the prevalence of C. calceolus is due to removal of C. macranthon from natural populations. For example, about 130 plants of C. macranthon, 15 of C. ventricosum and 3 of C. calceolus had been collected from natural habitats near the Sludynka River and planted in private gardens. Another 50 plants, mainly of C. macranthon were transplanted to the botanic garden in Irkutsk in 2002, 2004 and 2007 (The gene pool of plants included in the Red Book of the Russian Federation 2012).

C. macranthon outnumbered C. calceolus by more than seven times, however, hybrid plants occur in sympatric populations of Cypripedium in the Shushensky Pine Forest National Park and the Baikal-Lena Reserve. The sizes of the populations of C. calceolus and C. ventricosum recorded there were similar. However, the number of flowering shoots of Cypripedium can vary significantly from year to year: e.g. in 2014, the number of flowering shoots of C. macranthon was only half of that recorded in 2013, while for C. calceolus and C. ventricosum it was the same.

Only one individual of $C$. ventricosum was found in a sympatric population C. calceolus and C. macranthon in the Usinsk Basin. This could be due to the smaller overlap in the flowering periods of $C$. calceolus and C. macranthon there than that recorded in the Minusinsk Basin and the area surrounding Lake Teletskoye. A similar situation was recorded in sympatric populations of 


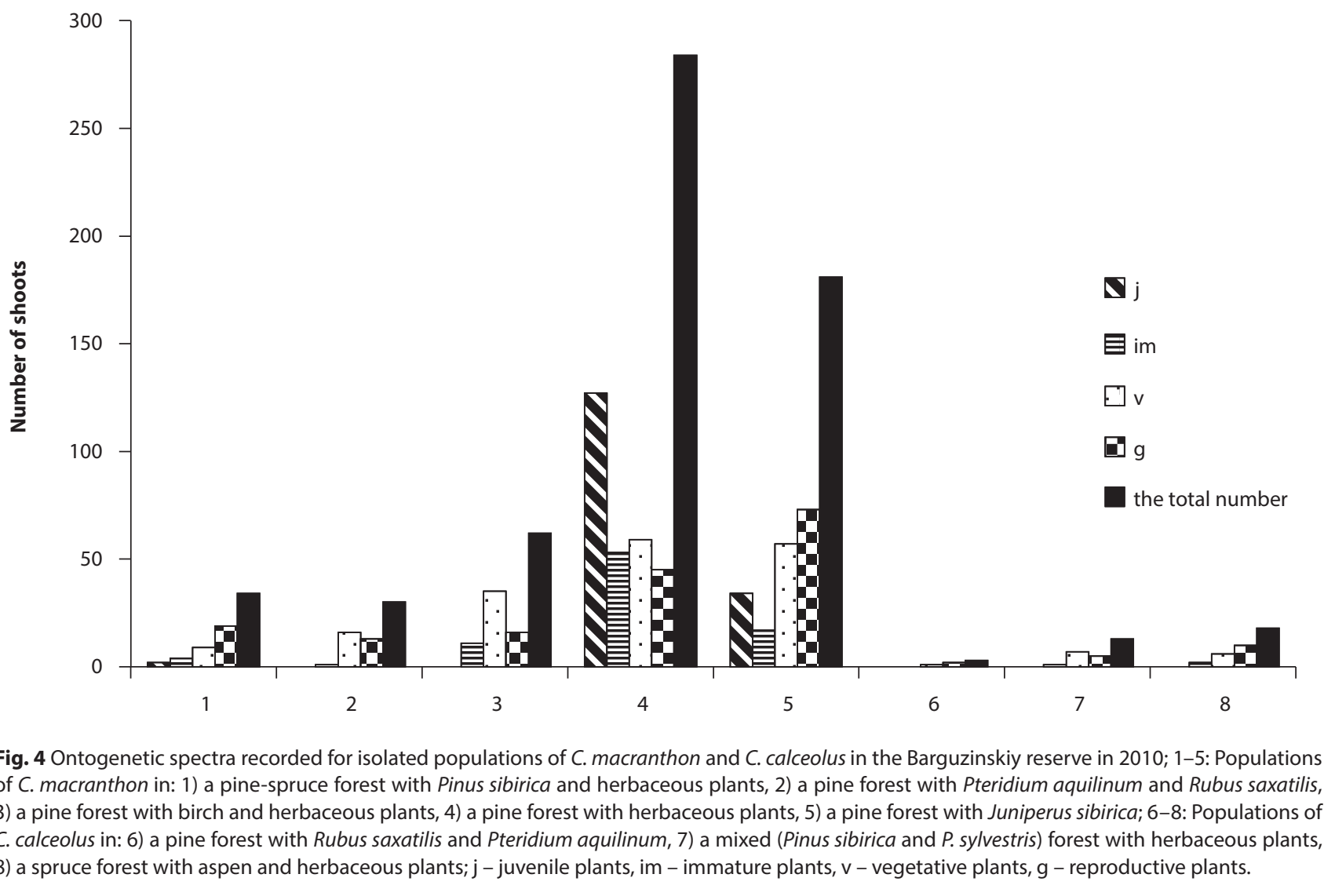

Table 1 Significant and non-significant parameters of flowering shoots of C. macranthon, C. calceolus and C. ventricosum revealed by the factor analysis (principal components).

\begin{tabular}{|c|c|c|c|c|}
\hline Parameters & C. macranthon & C. calceolus & C. ventricosum & C.m. C.c. - C.v. \\
\hline L shoot & + & + & + & + \\
\hline L leaf & + & + & + & - \\
\hline H leaf & + & - & + & + \\
\hline Lbr & + & - & + & + \\
\hline Hbr & + & + & + & + \\
\hline L dt & + & + & + & + \\
\hline H dt & + & + & + & + \\
\hline L It & + & + & - & + \\
\hline H lt & + & + & + & + \\
\hline Lit & + & + & + & + \\
\hline H it & + & + & + & + \\
\hline LI & + & - & + & + \\
\hline HI & - & - & + & + \\
\hline DI & - & - & + & + \\
\hline H lh & + & + & + & + \\
\hline Nht & & + & + & + \\
\hline
\end{tabular}

$\mathrm{L}$ shoot - shoot height; $\mathrm{L}$ leaf - the length of the second leaf; $\mathrm{H}$ leaf - the width of the second leaf; $\mathrm{L}$ br - the length of the bract; $\mathrm{H}$ br - the width of the bract; $\mathrm{L} \mathrm{dt}$ - the length of the dorsal outer petal (sepal); $\mathrm{H} \mathrm{dt}$ - the width of the dorsal outer petal; $\mathrm{L}$ It - the length of the lateral petal (sepal); $\mathrm{HIt}$ - the width of the lateral petal; $\mathrm{L}$ it - the length of the inner petal; $\mathrm{H}$ it - the width of the inner petal; $\mathrm{LI}$ - the length of the labellum; $\mathrm{HI}$ - the width of the labellum; D I - the depth of labellum; $\mathrm{H} \mathrm{Ih}$ - the width of the wrapped inside edge of the middle of the hole in the labellum; $\mathrm{N}$ ht - the number of half-turns in the spiral inner petal; + significant parameters; - non-significant parameters. 
Table 2 Mean measurements of some of the morphometric parameters of flowering shoots of C. macranthon, C. calceolus and C. ventricosum.

\begin{tabular}{|c|c|c|c|c|c|c|}
\hline \multirow{13}{*}{ 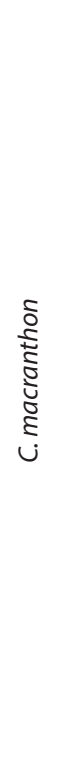 } & Species & mean \pm SD & mean $\pm S D$ & mean \pm SD & $\mathbf{F}$ & $p$ \\
\hline & & Total & Min & Max & & \\
\hline & L shoot & $30.94 \pm 6.18$ & $25.28 \pm 4.71(\mathrm{BLR})$ & $33.94 \pm 5.9(\mathrm{AR})$ & 18.74 & 0 \\
\hline & L leaf & $14.38 \pm 2.71$ & $11.93 \pm 2.01$ (BLR) & $16.32 \pm 2.29(\mathrm{AR})$ & 27.99 & 0 \\
\hline & H leaf & $7.11 \pm 1.77$ & $5.51 \pm 1.11(\mathrm{BLR})$ & $8.25 \pm 1.57(A R)$ & 22.70 & 0 \\
\hline & $L d t$ & $4.62 \pm 0.67$ & $4.21 \pm 0.59$ (BLR) & $4.98 \pm 0.65(\mathrm{AR})$ & 9.74 & 0 \\
\hline & $\mathrm{Hdt}$ & $3.38 \pm 0.5$ & $3.13 \pm 0.47(\mathrm{BLR})$ & $3.57 \pm 0.49(\mathrm{AR})$ & 5.22 & 0 \\
\hline & L It & $3.51 \pm 0.62$ & $3.13 \pm 0.67(\mathrm{BLR})$ & $3.78 \pm 0.57(A R)$ & 8.06 & 0 \\
\hline & $L$ it & $5.37 \pm 0.69$ & $5.07 \pm 0.62(\mathrm{BLR})$ & $5.73 \pm 0.67(A R)$ & 7.48 & 0 \\
\hline & $\mathrm{H}$ it & $1.96 \pm 0.36$ & $1.87 \pm 0.57(\mathrm{SI})$ & $2.04 \pm 0.37(A R)$ & 3.32 & 0.02 \\
\hline & LI & $4.52 \pm 0.64$ & $4.3 \pm 0.64(\mathrm{BLR})$ & $4.75 \pm 0.65(\mathrm{AR})$ & 4.04 & 0.01 \\
\hline & $\mathrm{HI}$ & $3.55 \pm 0.53$ & $3.35 \pm 0.5(\mathrm{BLR})$ & $3.76 \pm 0.56(\mathrm{AR})$ & 1.26 & 0.29 \\
\hline & DI & $2.44 \pm 0.30$ & $2.37 \pm 0.21(\mathrm{Shb})$ & $2.5 \pm 0.32(\mathrm{SI})$ & 13.88 & 0 \\
\hline \multirow{12}{*}{ 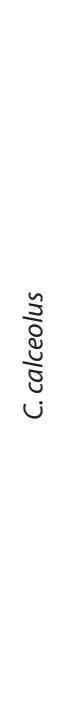 } & L shoot & $34.72 \pm 7.16$ & $29.53 \pm 5.61$ (BLR) & $38.49 \pm 5.62(\mathrm{Shb})$ & 7.74 & 0 \\
\hline & L leaf & $14.56 \pm 2.82$ & $12.21 \pm 2.43(\mathrm{SI})$ & $16.11 \pm 2.44(\mathrm{Shb})$ & 12.79 & 0 \\
\hline & H leaf & $7.20 \pm 1.70$ & $6.20 \pm 1.45(\mathrm{SI})$ & $8.31 \pm 1.44(\mathrm{AR})$ & 4.24 & 0.01 \\
\hline & $L d t$ & $4.84 \pm 0.67$ & $4.23 \pm 0.58$ (BLR) & $5.56 \pm 0.43(A R)$ & 17.48 & 0 \\
\hline & $\mathrm{Hdt}$ & $1.90 \pm 0.38$ & $1.59 \pm 0.31(\mathrm{BLR})$ & $2.20 \pm 0.22(\mathrm{AR})$ & 9.44 & 0 \\
\hline & LIt & $4.40 \pm 0.71$ & $3.74 \pm 0.69$ (BLR) & $5.01 \pm 0.51(\mathrm{AR})$ & 13.21 & 0 \\
\hline & Hlt & $1.64 \pm 0.26$ & $1.48 \pm 0.21(\mathrm{BLR})$ & $1.76 \pm 0.26(\mathrm{Shb})$ & 5.16 & 0 \\
\hline & L it & $4.9 \pm 0.81$ & $4.39 \pm 0.68$ (BLR) & $5.4 \pm 1.13(\mathrm{AR})$ & 3.93 & 0.01 \\
\hline & $\mathrm{H}$ it & $0.60 \pm 0.16$ & $0.50 \pm 0.10$ & $0.66 \pm 0.14(\mathrm{AR})$ & 2.39 & 0.08 \\
\hline & LI & $2.98 \pm 0.36$ & $2.77 \pm 0.32(\mathrm{BLR})$ & $3.23 \pm 0.24(\mathrm{AR})$ & 3.91 & 0.01 \\
\hline & $\mathrm{HI}$ & $1.94 \pm 0.32$ & $1.62 \pm 0.20(\mathrm{BLR})$ & $2.13 \pm 0.18(\mathrm{AR})$ & 7.26 & 0 \\
\hline & DI & $1.56 \pm 0.20$ & $1.54 \pm 0.16(A R$ & $1.58 \pm 0.23(\mathrm{Shb})$ & 0.05 & 0.98 \\
\hline \multirow{12}{*}{ 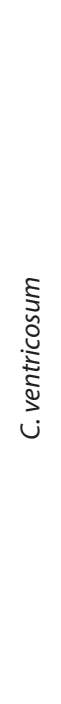 } & L shoot & $36.14 \pm 8.18$ & $27.35 \pm 7.77$ (BLR) & $41.68 \pm 7.86(\mathrm{AR})$ & 21.08 & 0 \\
\hline & L leaf & $14.30 \pm 3.16$ & $12.05 \pm 2.70$ (BLR) & $16.66 \pm 2.56(\mathrm{AR})$ & 8.94 & 0 \\
\hline & H leaf & $7.26 \pm 1.80$ & $5.79 \pm 1.76(\mathrm{BLR})$ & $8.45 \pm 2.06(\mathrm{AR})$ & 10.25 & 0 \\
\hline & $L d t$ & $5.02 \pm 0.68$ & $4.52 \pm 0.38$ (BLR) & $5.82 \pm 0.46(\mathrm{AR})$ & 19.65 & 0 \\
\hline & $\mathrm{Hdt}$ & $2.69 \pm 0.47$ & $2.34 \pm 0.42$ (BLR) & $3.10 \pm 0.42(\mathrm{AR})$ & 11.39 & 0 \\
\hline & L It & $4.26 \pm 0.58$ & $3.86 \pm 0.43$ (BLR) & $4.76 \pm 0.42(\mathrm{AR})$ & 10.32 & 0 \\
\hline & $\mathrm{HIt}$ & $2.33 \pm 0.34$ & $2.20 \pm 0.30$ (BLR) & $2.47 \pm 0.34(\mathrm{AR})$ & 2.14 & 0.13 \\
\hline & L it & $5.40 \pm 0.69$ & $4.9 \pm 0.35(\mathrm{BLR})$ & $6.24 \pm 0.60(\mathrm{AR})$ & 19.55 & 0 \\
\hline & $\mathrm{H}$ it & $1.12 \pm 0.20$ & $1.07 \pm 0.21(\mathrm{BLR})$ & $1.19 \pm 0.19(\mathrm{AR})$ & 1.24 & 0.30 \\
\hline & LI & $3.87 \pm 0.49$ & $3.65 \pm 0.46$ (BLR) & $4.05 \pm 0.49(\mathrm{AR})$ & 2.44 & 0.10 \\
\hline & $\mathrm{HI}$ & $2.72 \pm 0.38$ & $2.52 \pm 0.43(\mathrm{BLR})$ & $2.79 \pm 0.25(\mathrm{Shb})$ & 2.99 & 0.06 \\
\hline & DI & $2.06 \pm 0.19$ & $2.01 \pm 0.22(\mathrm{BLR})$ & $2.22 \pm 0.13(\mathrm{AR})$ & 5.76 & 0 \\
\hline
\end{tabular}

$L$ shoot - shoot height; $L$ leaf - the length of the second leaf; $H$ leaf - the width of the second leaf; $L \mathrm{dt}$ - the length of the dorsal outer petal (sepal); $\mathrm{H} \mathrm{dt}$ - the width of the dorsal outer petal; $\mathrm{L}$ It - the length of the lateral petal (sepal); HIt - the width of the lateral petal; $\mathrm{L}$ it - the length of the inner petal (petal); $\mathrm{H}$ it - the width of the inner petal; $\mathrm{LI}$ - the length of the labellum; $\mathrm{HI}$ - the width of the labellum; $\mathrm{DI}$ - the depth of labellum; $\mathrm{N}$ ht - the number of half-turns in the spiral inner petal; AR - Altai Nature Reserve; Shb - Shushensky Pine Forest National Park; BLR - Baikal-Lensky Nature Reserve; $\mathrm{SI}$ - Southern Baikal (Sludyanka); significant differences are in bold. 
C. calceolus and C. macranthon growing on the shores of Lake Baikal in the southern Baikal area in 2014. Sympatric populations of C. macranthon and C. ventricosum in which there are no C. calceolus and isolated populations of $C$. ventricosum were recorded in the Altai Nature Reserve. Hybrid plants could have been a result of pollinators' transferring C. calceolus pollen over a long distance.

The non-flowering stages of these three species of Cypripedium are indistinguishable from one another. The non-flowering shoots of Cypripedium were mainly mature in all the populations studied and illustrated in Fig. 3 for the Altai Nature Reserve. Success of reproduction by seed in Cypripedium populations was estimated based on the number of juvenile plants. The percentage abundance of juvenile plants in the populations studied was $1.1-8.0 \%$.

Isolated populations of Cypripedium calceolus occurred in pine, larch, spruce and birch forests in the south of the Krasnoyarsk region (Usinsk Basin) and on the northeastern coast of Lake Baikal (Barguzinsky Nature Reserve). C. calceolus was most abundant in a birch forest in the Usinsk Basin (246 shoots), where the average number of shoots was $0.001-13.0 \mathrm{~m}^{-2}$.

Isolated populations of Cypripedium macranthon occurred in both pine and pine with birch and aspen forests. C. macranthon was most abundant in the mixed pine with birch forest in the Barguzinsky Nature Reserve (527 shoots), where the average number of shoots was 0.1-5.6 $\mathrm{m}^{-2}$. Maximum sizes of isolated populations of C. calceolus and C. macranthon were significantly smaller than those of sympatric Cypripedium populations in the Minusinsk Basin.

In most isolated populations, mature vegetative and reproductive plants clearly dominated, which corresponds to the basic spectrum for this species, which indicates that vegetative reproduction is most successful (Tatarenko 1996). Juvenile plants made up $44.7 \%$ of one of the C. macranthon populations in the Barguzinsky Nature Reserve (Fig. 4). This was probably a result of favourable weather combined with optimal illumination and the fact that plants were growing on limestone outcrops. Juvenile plants were not recorded in small populations of C. calceolus in the Usinsk Basin and Barguzinsky Nature Reserve.

Factor analysis (principal components) revealed which parameters are significant for the differences between populations and species (Table 1).

One-way ANOVA revealed significant differences for most of parameters studied, except the number of leaves, number of ribs, the length of the hole in the labellum measured from the staminode to the forefront, the width of the wrapped inside edge of the hole in the labellum measured in the middle and the length of the free parts of the lateral petal (Table 2). The parameters of the $C$. ventricosum flowers are intermediate between its parental species, C. calceolus and C. macranthon. Similar peculi- arities of these three species have been recorded in the Urals (Knyazev et al. 2000). C. macranthon, C. calceolus and $C$. ventricosum plants were bigger in populations in wet forests in the warmer western regions: the Altai Nature Reserve (AR) and the southern part of the Krasnoyarsk Territory (Shushensky Pine Forest National Park (Shb)). The plants growing on dry limestone slopes in the Baikal-Lensky Nature Reserve were smaller (Table 2). Two habitat-dependent forms of C. calceolus were also recorded growing in the Komi Republic: plants growing in wet forests and swamps were taller than those growing on dry limestone slopes (Martynenko et al. 2003).

Five colour variations of $C$. ventricosum were recorded. Hybrid plants with typically coloured perianth (dark pink with white) dominate in $C$. ventricosum populations; hybrid plants with pink petals and a white labellum or with dark red petals and a yellow labellum with red or orange veins were rare.

Typical colour of the perianth was recorded more frequently than the atypical colour, which was rare. In the Shushensky Pine Forest National Park in 2011 the colour of the perianth of between 21.4 and $34.9 \%$ of the C. ventricosum plants was atypical (Fig. 5). Such plants (mainly with dark red petals and yellow labellum with with red or orange veins) were likely to be the result of backcrossing of C. ventricosum with C. calceolus. Similar coloured flowers were recorded in the Altai Nature Reserve and on the Khamar-Daban Ridge. Plants with a white labellum were extremely rare.

The percentage of plants fruiting in sympatric populations of Cypripedium was measured in the Shushensky Pine Forest National Park in 2011. The highest percentage was recorded for $C$. macranthon and the lowest for C. ventricosum (Fig. 6). Pollen of C. ventricosum can be fully or partially sterile (Andronova 2011). The induction of fruit in C. ventricosum is most often a consequence backcrossing with one of the parental forms. In the habitats surveyed in the current study and in the Urals (Knyazev et al. 2000), the low percentage fruiting

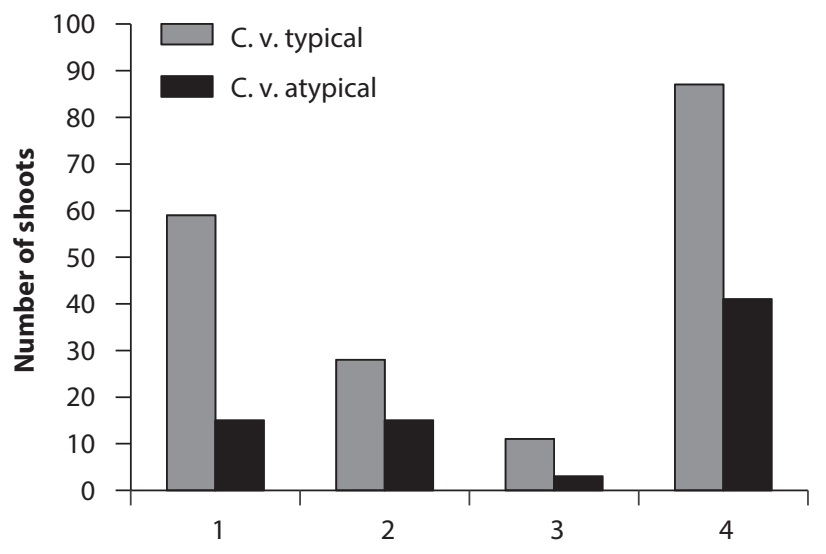

Fig. 5 The number of flowering shoots with typically and atypically coloured perianths recorded in $C$. ventricosum populations in the Shushensky Pine Forest National Park in 2011. 


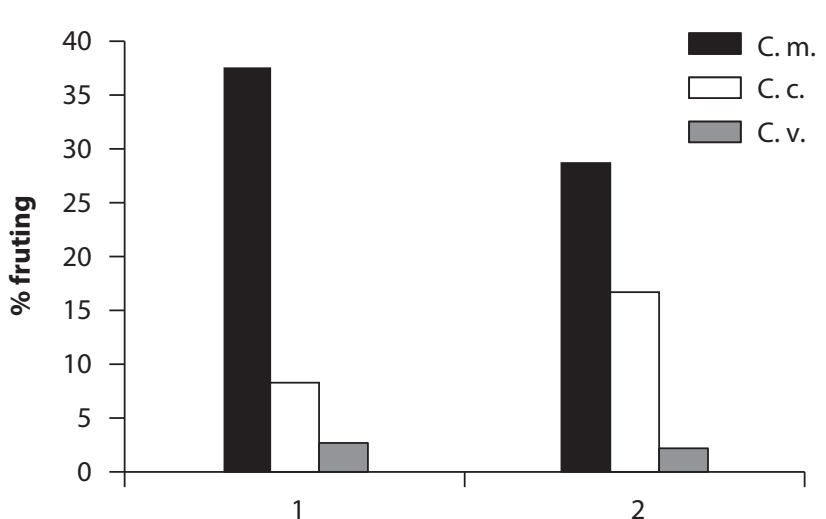

Fig. 6 Percentage of plants recorded fruiting in populations of Cypripedium in the Shushensky Pine Forest National Park in 2011.

plants of C. calceolus was possibly due to competition with $C$. macranthon for pollinators, the latter has larger and brighter flowers.

\section{Conclusions}

1. The largest sympatric populations of Cypripedium were recorded in the Minusinsk Basin in the south of the Krasnoyarsk territory.

2. The plants of C. macranthon dominated in most sympatric populations of Cypripedium, which is apparently typical of populations of these species in the central part of the area studied but not the more western parts, where C. calceolus plants dominated.

3. Mature vegetative and/or reproductive shoots and vegetative reproduction clearly dominated the ontogenetic structure of most of the populations investigated, which is the basic spectrum for these species.

4. Important interspecific differences were recorded in shoot height, bract length, bract width, width of dorsal outer petal, length of lateral petal (sepal), width of lateral petal, length of inner petal, width of inner petal, length of labellum, width of labellum, depth of labellum and number of half-turns in the spiral inner petal.

5. Intraspecific (inter-population) differences were recorded in the length of the shoot, leaf parameters, length of dorsal outer petal (sepal), width of dorsal outer petal, length of lateral petal (sepal), width of lateral petal, length of inner petal, length of labellum, and width of the labellum. Plants of C. macranthon, C. calceolus and C. ventricosum growing in wet forests in the warmer western regions of the Altyi and the southern part of the Krasnoyarsk Territory were the biggest and the smallest were those growing on dry limestone slopes in the Baikal-Lensky Nature Reserve.

6. Hybrid plants with a typically coloured perianth were dominant in $C$. ventricosum populations.

7. The highest percentage of fruiting plants was recorded for C. macranthon, possibly because it wins in competition for pollinators with C. calceolus. C. ventrico- sum, for which lowest percentage fruiting was recorded in sympatric populations in the Shushensky Pine Forest National park, where it fruits only when it backcross with one of the parental forms.

\section{Acknowledgements}

I am grateful to Vladimir Storozhev, Nikolay Stepanov, Natalia Suprankova, Inna Lipilina, Evgeniya Buharova, Elena Koroleva, Nadezhda Stepantsova and Oleg Zhelezniy for help with the field work. Many thanks to Irina Tatarenko, Mike Dodd, Sylvia des Tombe, Elena Tihonova and Vladimir Korotkov for comments on earlier versions of this manuscript and help with the English. Many thanks to Ivan Schanzer and Pavel Grabarnik for help with statistical programs. Thanks to Alexandra Nikolaeva for help with plotting the map. Many thanks to Elena Chusova - director of Timiryazev State Biological museum for long-term support of my work.

\section{REFERENCES}

Andronova EV (2011) To a question about the reasons for the formation of low-quality seeds of some orchids of temperate latitudes. In: Shamrov II (ed) Protection and Cultivation of Orchids, pp. 16-26. Proceedings of the IX International Conference, Moscow. (In Russian)

Averyanov LV (1999) Genus Lady's-slipper - Cypripedium (Orchidaceae) in Russia. Turczaninowia 2: 5-40. (In Russian)

Braun-Blanquet J (1964) Pflazensoziologie. 3. Aufl., Wien-New York: Springer.

Dementieva SM (1985) Lady's Slipper (Cypripedium calceolus L.) in forest ecosystems. In: Smirnov AV (ed) Mutual relations components of biogeocenosis in the southern taiga, pp. 36-46. Kalinin State University, Kalinin. (In Russian)

Gatsuk LE, Smirnova OV, Vorontzova LI, Zaugolnova LB, Zhukova LA (1980) Age stages of plants of various growth forms: a review. J Ecol Bd 68: 675-696.

Ishmuratova MM, Suyundukov IV, Ishbirdin AR, Zhirnova TV, Naibullin MI (2003) The state of cenopopulations of some species of the Family Orchidaceae in the southern Urals. Message 2. Rhizomatous species. Plant Resour 39: 18-37. (In Russian)

Knyazev MS, Kulikov PV, Knyazev, OI, Semerikov VL (2000) About interspecific hybridization of Eurasian species of the genus Cypripedium (Orchidaceae) and taxonomic status of C. ventricosum. Bot J 85: 94-102. (In Russian)

Mamaev SA, Knyazev MS, Kulikov PV, Filippov EG (2004) Orchids of the Urals: systematics, biology, conservation. Ekaterinburg. Ur. Dep. RSA. (In Russian)

Martynenko VA, Poletaeva AI, Teteryuk BY, Teteryuk LP (2003) Biology and ecology of rare plants of the Komi Republic. Ekaterinburg Ur. Dep. RAS. (In Russian)

Puchnina LV (1999) The state of cenopopulations of Cypripedium calceolus (Orchidaceae) in karst landscapes it the north of European Russia. Bot J 84: 75-82. (In Russian)

Rabotnov TA (1950) The life cycle of perennial herbaceous plants in the meadow cenoses. Proceedings of the Botanical Institute AS SU, Geobotany 6: 7-204. (In Russian) 
Smirnov AV (1969) About changing the positions of some orchids in the forests of Central Siberia, which was disturbed by anthropogenic factors. Scientific Reports of high school. Biological Sciences 8: 79-83. (In Russian)

Tatarenko IV (1996) Orchids of Russia: life forms, biology, protection. Moscow. (In Russian)

Teteryuk LV (2003). In: Ushakova KN (ed) Lady's-slipper. Biology and Ecology of Rare Plants in the Komi Republic, pp. 28-42. Ur. Dep. of RSA, Ekaterinburg, Russia. (In Russian)

The Red Book of the Russian Federation (plants and fungi) (2008). Moscow. (In Russian)

Terschuren J (1999) Action plan for Cypripedium calceolus in Europe. Nature and environment no. 100. Council of Europe Publishing, Strasbourg.

The gene pool of plants of the Red Book of the Russian Federation stored in the collections of botanical gardens and arboreta (2012). Moscow. (In Russian)

Uranov AA (1975) Phytocenopopulation age spectrum as a function of time and energy of wave processes. Biological Sciences 2: 7-34. (In Russian)
Vakhrameeva MG, Tatarenko IV (1998) Age structure of populations of orchids with different life forms. Acta Univ Wratislaviensis 2037: 129-139.

Vakhrameeva MG, Tatarenko IV, Varlygina TI, Torosyan GK, Zagulskii MN (2008) Orchids of Russia and adjacent countries (within the borders of the former USSR). Ruggell (Liechtenstein), A. R. G. Gantner Verlag.

Varlygina TI, Matsenko AE (1987) Comparative characteristics of two cenopopulations of Cypripedium calceolus in the Moscow region. In: Vakhrameeva MG (ed) Conservation and Cultivation of Orchids, pp. 24-25. Nauka. Moscow, Russia. (In Russian)

Zaugolnova LB, Nikitina SV, Denisova LV (1992) Types of functioning the populations of rare plant species. Bulletin of Moscow Society of Naturalists. Department of Biology 97: 80-91. (In Russian)

Zaugolnova LB, Zhukova LA, Komarov AS, Smirnova OV (1988) Cenopopulation of plants (Notes of population biology). Moscow. (In Russian) 